\title{
IMPACT OF BANKING GROUP'S MANAGEMENT POLICIES AND COUNTRY ENVIRONMENT ON BANK'S MODEL OF OPERATION
}

\author{
Jozefina Beke-Trivunac
}

ALFA BK University, Belgrade, Serbia

\begin{abstract}
:
The objective of this paper is to seek to identify which of two factors: (1) the banking group management policies, or (2) the country in which the bank operates, has higher impact on the bank's model of operation measured in terms of three ratios: net fee and commission income compared to net interest income, impairment losses on loans compared to net interest income and net fee and commission income compared to personnel expenses. The analysis included 29 banks affiliated in four banking groups and nine CEE countries during the period 2014 and 2015. The results show that the country environment has much higher impact on banks' operations than their management policies.
\end{abstract}

Keywords:

cross-country analysis of banks, efficiency of banks' operations, bank business model, banks in CEE countries.

\section{INTRODUCTION}

Revenue from interests, fees and commissions is the most important source of the bank's income. Interest income, that i, money earned by lending out customers' deposits in various forms of loans, makes the most significant part of banks' income. Fee income is the revenue taken in by banks from account-related charges to customers. Fees and commissions consist mainly of fees charged on payment services, credit cards, services and fund management on behalf of legal entities and citizens, together with commissions from guarantees. Fee income and acquisition costs related to loan origination are usually capitalized and included in the effective interest rate and recognized as interest income over the expected life of the loan.

This paper analyses the magnitude of net interest income and net fee and commission income of the banks that are members of one of the four banking groups (Banca Intesa, UniCredit, Raiffeisen and Societe Generale) within nine Central and Eastern European (CEE) countries, the trend of the extent of net interest income (i.e. interest income less interest expenses) used to cover bad loan losses in 2014 and 2015, as well as the trend of net fee and commission income (i.e. fee and commission income less fee and commission expenses) used to finance personnel expenses. In other words, the paper analyses the efficiency by means of which certain segments of income finance certain costs.

The usual approach to banks' efficiency analysis is to compare various trends in "costs to income ratio" as an overall indicator of cost effectiveness. Costs to income ratio measures income generated per monetary unit cost. The lower the value of this ratio, the better the performance of the bank. According to Raiffeisen RESEARCH (Raiffeisen, 2016), which analyses CEE banking sector in 2014 and 2015, the results of efforts of surveyed banks to slow down costs had different results over the period and by different banks. UniCredit is the only bank in CEE that was able to reduce the
Correspondence:

Jozefina Beke-Trivunac

e-mail:

trivunci@orion.rs 
Table 1. Cost/income ratio (\%)

\begin{tabular}{|c|c|c|c|c|c|}
\hline Bank & 2011 & 2012 & 2013 & 2014 & 2015 \\
\hline Banca Intesa & 47 & 52 & 52 & 52 & 50 \\
\hline Raiffeisen bank & 56 & 58 & 57 & 56 & 55 \\
\hline Societe Generale & 54 & 58 & 53 & 58 & 62 \\
\hline UniCredit & 46 & 46 & 44 & 42 & 41 \\
\hline
\end{tabular}

Source: Raiffeisen research, CEE Banking Sector Report, June 2016, p. 59, 65, 67, 71.

cost/income indicator from 46 in 2011 to 41 in 2015. The values of Banca Intesa and Societe Generale's cost/income ratio significantly increased over the same period, while the value of Raiffeisen bank's cost/income ratio was almost the same at the beginning and end of the period.

This study is focused on examination of the components of banks' income and expenses, starting from the idea that interest income represents "time value of money" used, while fee and commission income is "earned" by various non-lending activities. The ability of banks to finance personnel expenses, as part of total operating expenses, by net fee and commission income, as part of total income, may be an indicator of the extent of supreme knowledge, or supreme technology, or supreme management, or similar capabilities deployed as intellectual and human capital. According to the International $<\mathrm{IR}>$ framework, intellectual capital represents "organizational, knowledge-based intangibles, including "organizational capital" such as tacit knowledge, systems, procedures and protocols", while human capital represents "people's competencies, capabilities and experience, and their motivations to innovate, including ... their loyalties and motivations for improving processes, goods and services ..." (IIRC, 2013, p. 12). According to Hoffmann, the efficient-structure hypothesis says that banks with superior management or production technologies have lower costs (Hoffmann, 2011, p. 258).

Moreover, almost all banks make special effort to further improve their capabilities by introduction of new technologies, especially in the area of digital banking due to minimum investment in fixed assets and further opportunities for reduction of labor costs and increase of fee income. Coverage of staff expenses illustrates the efficiency of the employee working time as a result of their activity (Monea, 2011).

The postulate that impairment on loan losses shall be covered by net interest income seems natural. Banks earn interest income based on lended assets, and losses on impaired assets shall be, naturally, covered by interest income.

The studies of income and expenses of banks in CEE countries support the premise on interest income and fee and commission income as the most significant elements of CEE banks income, and the cost of loan losses and personnel costs as the most significant expenses. For example, the analysis of the structure of income and expenses of Roma- nian banks reveals that over $90 \%$ of banks' income is found in net interest income and net fee and commission income. On the other side, the larger part of banks' expenses is found in the impairment loss on financial assets and staff expenses.

The objective of the cross-country analysis of banks which are members of the same banking groups is to identify which of two factors, the residence in the same country or belonging to the same banking group has higher impact on the results of an individual bank's operation measured in terms of three ratios: net fee and commission income compared to net interest income (NFCI/NII), impairment losses on loans compared to net interest income (ILL/NII) and net fee and commission income compared to personnel expenses (NFCI/PE).

Namely, the results of the empirical analysis of competitive conditions in banking systems of the CEE countries over the period 1999-2006 conducted by Delis suggests that the bank's revenue is substantially influenced by structural and macroeconomic conditions of the country in which the bank operates (Delis, 2008). Previous research on the performance of 515 banks in 16 transition economic during the period 1994-99 indicate that banks' performances differ significantly depending on the environment in which they operate (Fries et al., 2002). Also, the findings of Dietsch and Lozano-Vivas' research on the influence of environmental determinants on banking efficiency confirm their belief that environmental variables are an important factor in explaining differences in international banking efficiency (Dietsch \& Lozano-Vivas, 2000, p. 1000). Cross-country efficiency studies in the banking industry have generally attracted a lot of attention, but it is difficult to find studies which compared banks' efficiency for the same group of banks within different countries.

\section{METHODOLOGY AND DATA COLLECTION}

This paper seeks to examine which of two factors, banking group's policies or the country environment, has higher impact on the sufficiency of the bank's net interest income to cover impairment loan losses and net fee and commission income to cover personal expenses. The study is conducted on the panel of banks operating in the CEE region, belonging to four large banking groups, over a two-year period. The use of panel data is the most suitable tool when the sample comprises of cross-sectional and time-series data. Panel 
data include banks which operate in the CEE countries, and which belong to four significant banking groups: Intesa, Raiffeisen, Societe Generale, and UniCredit. The sample contains 29 banks from 9 countries. Out of the total number of banks, 3 are in Albania, 3 in Bulgaria, 4 in Croatia, 3 in the Czech Republic, 3 in Hungary, 4 in Romania, 2 in the Slovak Republic, 3 in Slovenia, and 4 in Serbia. Data for individual banks are annual and they include information obtained from income statements. The herein observed banks account for the vast majority of banking operations in their respective countries. The selection of these banks is based on their relatively large size and vast diversification in the region. These four banking groups are well diversified geographically across various CEE markets, even though each of them is present in some markets and absent in others.

For the purpose of this paper, data have been gathered from publicly available banks' annual reports and financial statements for the year 2015 (the list of banks is at the end of this paper).

The paper analyses absolute values of three indicators: net fee and commission income compared to net interest income (NFCI/NII), impairment losses on loans compared to net interest income (ILL/NII) and net fee and commission income compared to personnel expenses (NFCI/PE). The indicators used in this text are very simplistic metrics applied on figures from the income statements for 2015 and 2014 therefore, deductions about the bank's efficiency throughout the examined segments using these measures should be interpreted with caution.

The research results are presented in very simple way, mainly using graphs and charts in order to enable visual experience. The research also includes a few common simple metrics in the form of "common average", as the first step needed for higher level overview.

\section{RESULTS AND DISCUSSION}

This section analyses distribution of the results /concerning the analysis of relationship between "net fee and commission income and net interest income", "impairment losses on loans and net interest income", and "net fee and commission income and personnel expenses" of 29 banks that are members of the four banking groups and which are affiliated in nine CEE countries, as well as their trends over a two-year period.

\section{RELATIONSHIP BETWEEN "NET FEE AND COMMISSION INCOME" AND "NET INTEREST INCOME"}

Distribution of country average ratios ,net fee and commission income / net interest income" (NFCI/NI) varies by countries from the lowest of 0.15 for Albania to the highest of 0.81 for Hungary in 2015. Based on the ratio values, we can identify three groups of countries. The first group includes Albania and Serbia, which are the countries with the lowest NFCI/NII ratio. The second group includes Croatia, Slovakia, the Czech Republic and Bulgaria, with a very stable $\mathrm{NFCI} / \mathrm{NII}$ ratio in the range from 0.33 to 0.36 in 2015. The third group, with high NFCI/NII ratio in the range from 0.44 to 0.81 , includes Romania, Slovenia and Hungary.

The dynamics of movements of NFCI/NII between 2014 and 2015, measured by annual index, vary from the lowest of 0.98 for the Czech Republic to the highest 1.18 for Slovakia. Based on the index value, we can identify three groups of countries. The first one includes the Czech Republic and Romania with negative movements of the annual index ( 0.98 - 0.99). The second group includes Serbia, Croatia and Slovenia with slight movements of this index $(1.03-1.05)$, and the third group includes countries with very dynamic movements of the annual index such as Albania, Slovakia, Bulgaria and Hungary $(1.09-1.15)$.

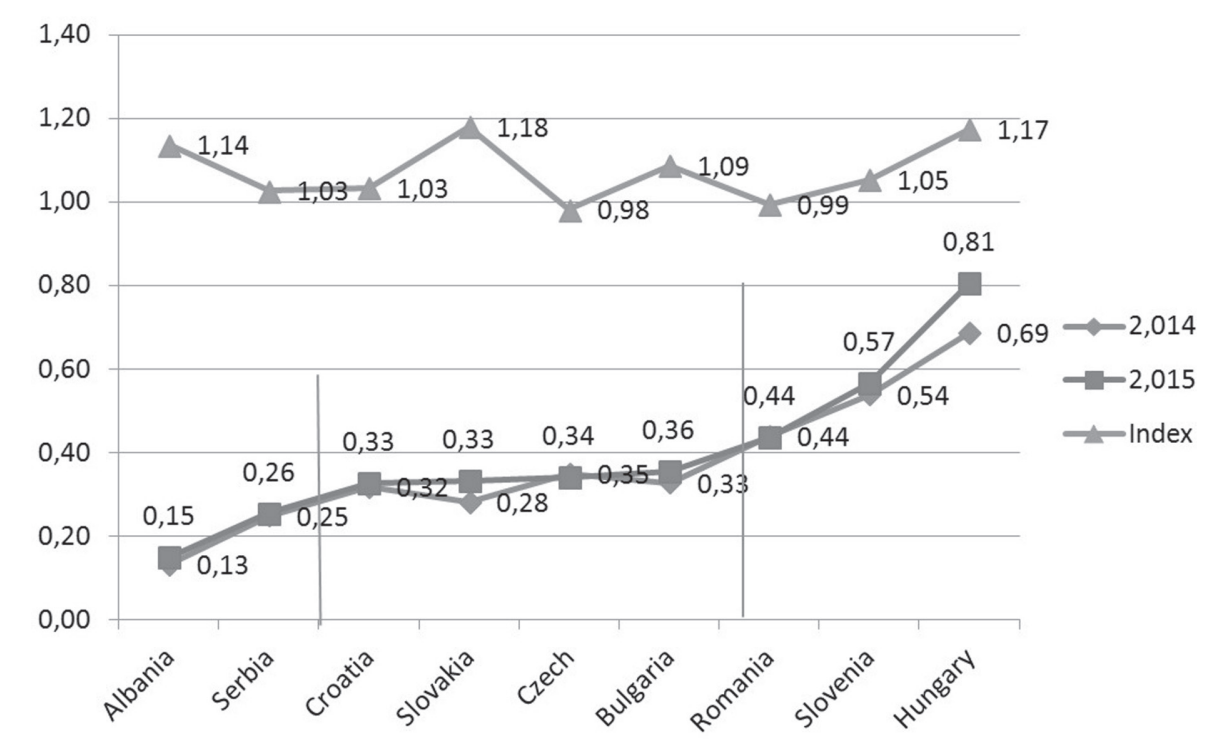


The analysis by bank groups reveals that distribution of ratios NFCI/NII varied by bank groups from 0.33 for Societe Generale to 0.43 for UniCredit in 2015. Moreover, the UniCredit had the highest NCFI/NII ratio in the previous year, too. The dynamics of movements of NFCI/NII between 2014 and 2015 by banks, measured by annual index, varied from negative (0.97) for Societe Generale, to moderate (1.01-1.07) for Raiffeisen and Uni Credit, up to the highest of 1.15 for Banca Intesa.

Further details on the presented averages can be achieved by the analysis of the NFCI/NII ratios of individual banks by countries and by bank groups. The results are presented in Chart 1. The data presented in this chart reveal similarities and differences among individual banks within different countries. The general trend based on the analysis by countries is that income of all banks follows similar pattern in most countries. The NFCI/NII ratios of Albanian banks are the lowest ones, within the range of 0.12 and 0.17 . The same ratios for Serbian banks are within the range of 0.19 and 0.34 , for Croatian banks are within the range of 0.30 and 0.36 , for Slovak banks are within the range of 0.30 and 0.36 , for Czech banks are within the range of 0.30 and 0.39 , for Bulgarian banks are within the range of 0.32 and 0.43 , for Romanian banks are within the range of 0.22 and 0.58 , for Slovenian banks are within the range of 0.54 and 0.60 and for Hungarian banks are within the range of 0.61 and 0.86 . The rank of banks based on the value of NFCI/NII ratio within individual countries varies from country to country.

The analysis of these differences should consider the fact that most of these banks have been transforming themselves into financial groups by adding subsidiaries, in order to offer additional services (Delis, 2009, p. 6). On the other hand, some banks incorporate additional activities within an individual entity's own activities and present them in their separate financial statements. These developments resulted in significant modifications in the balance sheets and income statements of these banks, and must be taken into account when conclusions are made.

Visual presentation of individual banks' NFCI/NII ratio weights in the chart above clearly shows that the weights of indicators for different banks within the same country are much more similar to each other than they are within the same group of banks.

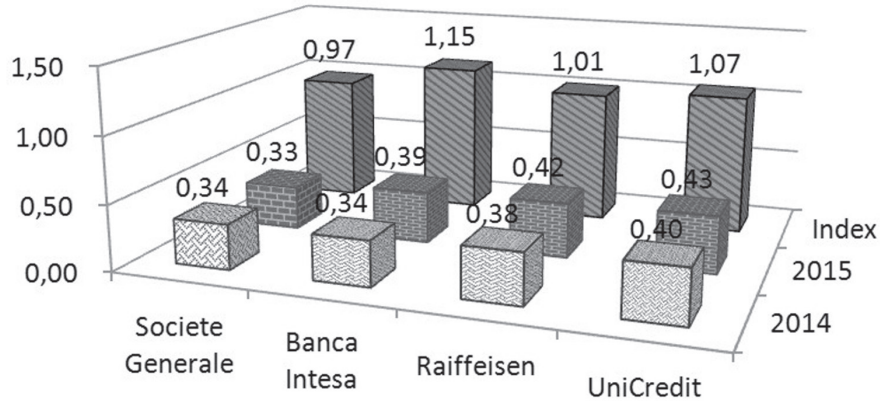

图2014 国2015 Index

Figure 2. Net fee and commission income compared to net interest income by selected banks - NFCI/NII ratio

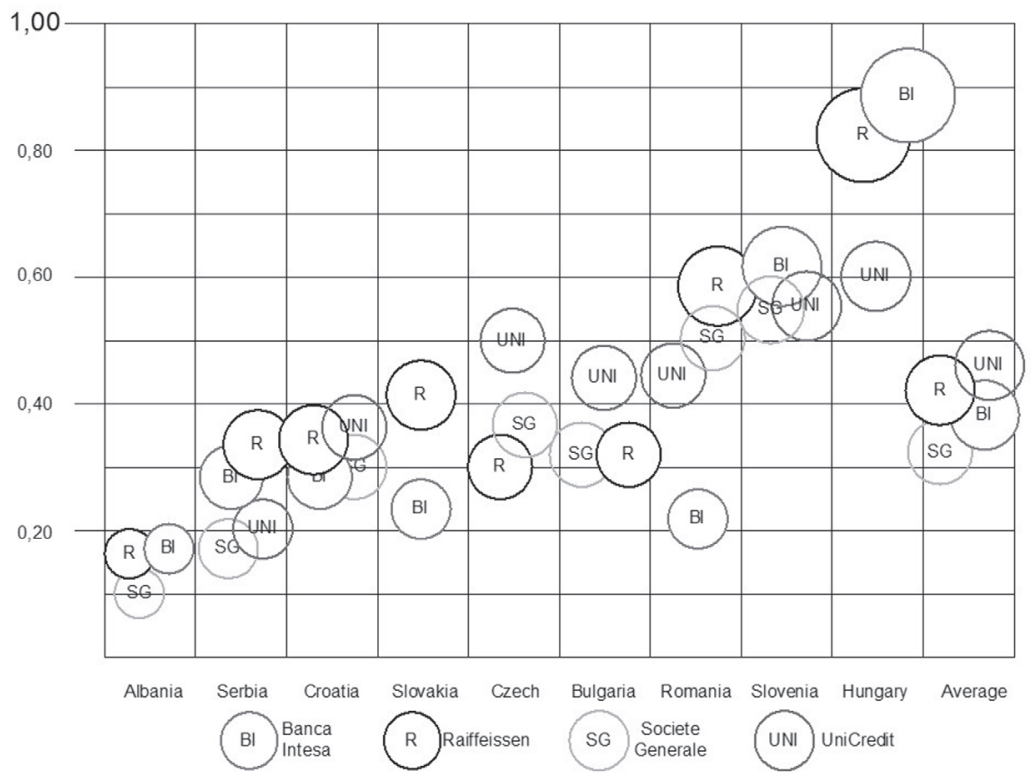




\section{RELATIONSHIP BETWEEN “IMPAIRMENT LOSSES ON LOANS" AND "NET INTEREST INCOME"}

Taking deposits and placing loans out of these deposits is the core business of banks. Related income arises out of extended loans in the form of interest income and related costs arise out of deposits in the form of interest expenses. Default banking risk relates to losses on non-performing loans, and the cost of this risk should be covered by net interest income. Banks' income statements sometimes report their financial results following such reporting pattern.

Distribution of country average ratios "impairment losses on loans / net interest income" (IIL/NII) varied in the range from 0.12 for Czech to 0.50 for Hungary in 2015, and from 0.09 for Czech and 1.27 for Hungary in 2014. Czech and Slovak banks' loan portfolios were the healthiest banks at that time. On the contrary, Hungarian and Romanian banks experienced the greatest loan losses compared to their net interest income in both years, especially in 2014. Distribution of ILL/NII ratio by countries is presented in Figure 3.

The analysis of ILL/NII ratio by banks, as presented in Figure 4, shows that all banks experienced higher impairment loan losses compared to net interest income in 2014 than in 2015. Raiffeisen bank and Banca Intesa had a very high ILL/NII ratio in 2014, but significantly lower one in 2015. UniCredit ILL/NII ratio was almost the same in both years. Societe Generale bank's ILL/NII ratios were the lowest in both years.

To avoid high variances among the banks during two years, we calculated summarized ILL/NII ratio for two years (the sum of ILL for 2014 and 2015 divided by the sum of NII for both years), by banks and by countries. The analysis of results reveals that Raiffeisen bank in Hungary had ultimately the worst experience among all banks (summarized ILL/NII $=1.53$ ), followed by Banca Intesa in Romania (summarized ILL/NII = 1.26), and Banca Intesa in Hungary (summarized $\mathrm{ILL} / \mathrm{NII}=1.05)$.

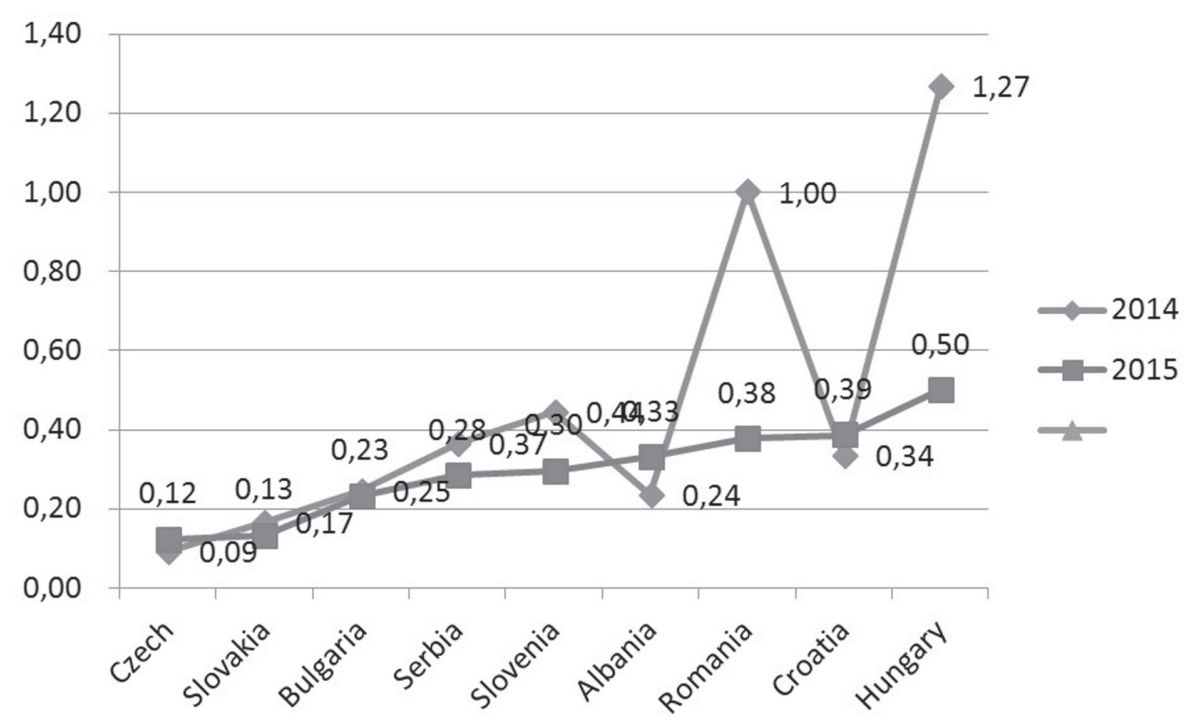

Figure 3. Impairment losses on loans compared to net interest income by countries - ILL/NII ratio 


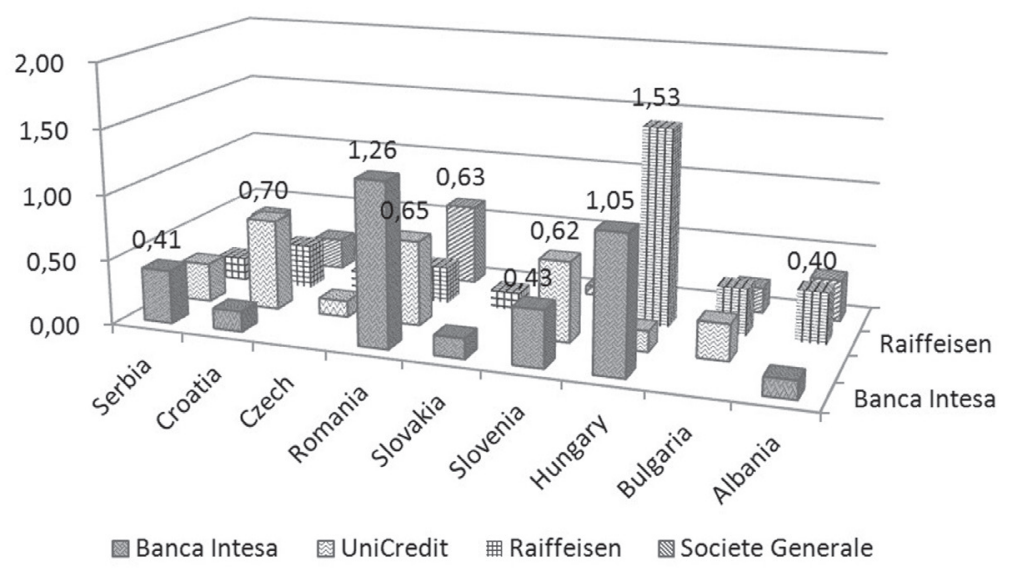

Figure 5. Impairment losses on loans compared to net interest income by banks and countriessummarized ILL/NII ratio for two years

\section{RELATIONSHIP BETWEEN "NET FEE AND COMMISSION INCOME" AND "PERSONNEL EXPENSES"}

With the exception of Bulgaria and Hungary, banks' net fee and commission income are usually not sufficient for financing personnel expenses. The share of personnel expenses financed by net fee and commission income was the lowest in Albania both in 2014 (55\%) and 2015 (61\%). The share of personnel expenses in Romanian, Slovenian,
Croatian, Serbian, Czech and Slovak banks varied from 85\% to $93 \%$ in 2014 , and from $79 \%$ do $97 \%$ in 2015 . Bulgarian and Hungarian banks are able to finance their personnel expenses fully by net fee and commission income.

Higher weights of "net fee and commission income / personnel expenses" (NFCI/PE) ratios in 2015 than in 2014, in all countries except Romania, is the most significant characteristic of (NFCI/PE) trend. The distribution of average NFCI/PE ratio by countries is presented in Figure 6.

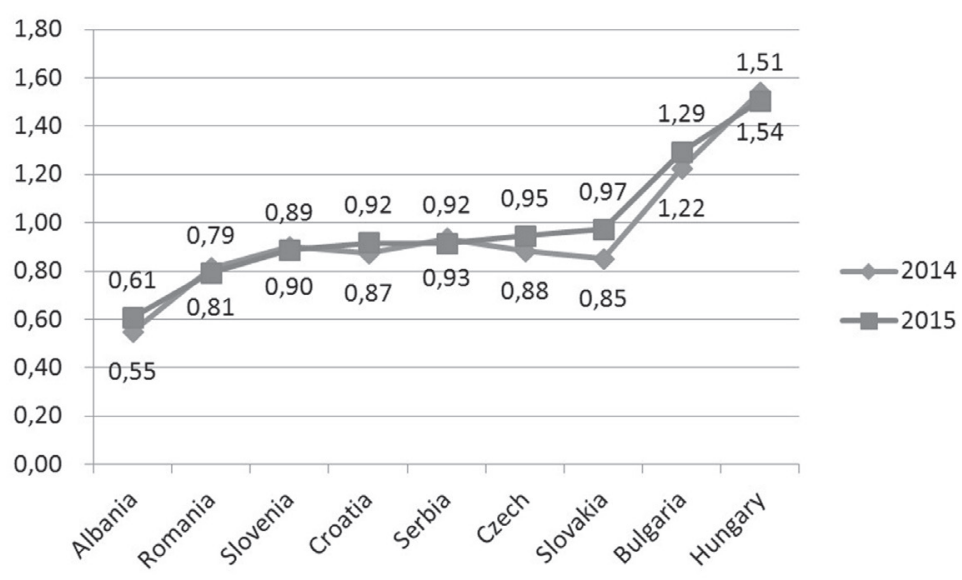

Figure 6. Net fee and commission income compared to personnel expenses (NFCI/PE) by countries

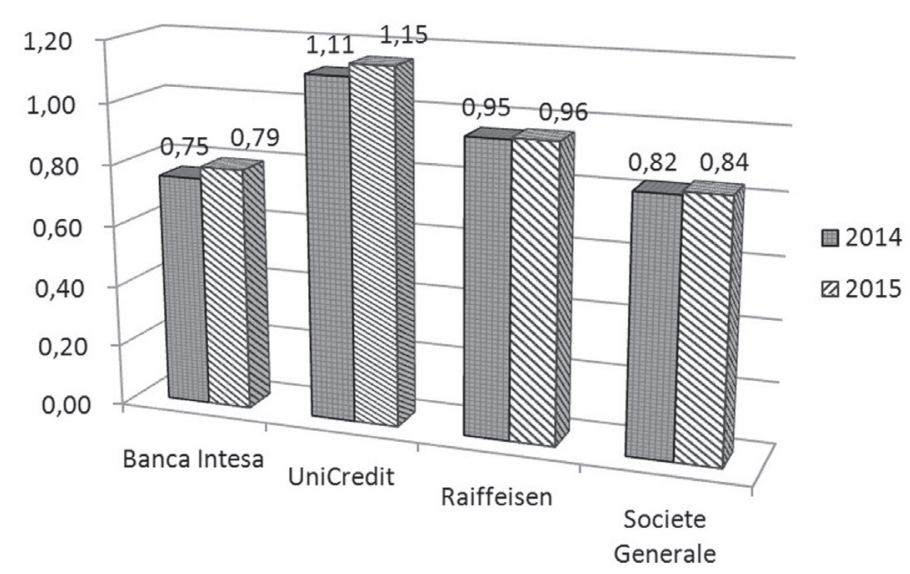

Figure 7. Net fee and commission income compared to personnel expenses (NFCI/PE) by banks 


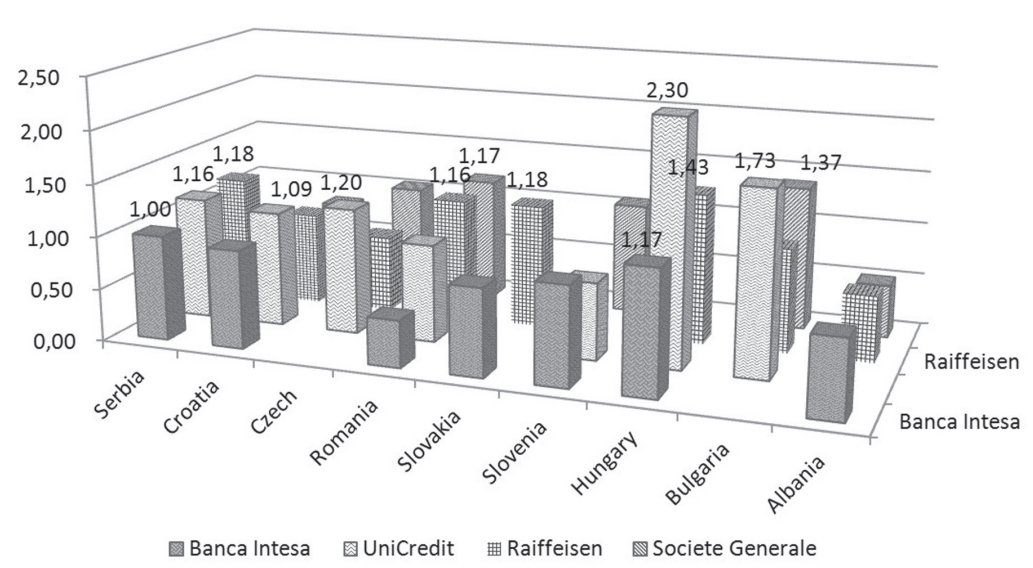

Figure 8. Net fee and commission income compared to personnel expenses (NFCI/PE) by banks and countries in 2015

The analysis by banks reveals that UniCredit bank is the only one able to finance its personnel expenses from net fee and commission income. Higher value of NFCI/PE ratios in 2015 than in 2014 is the most significant characteristic of its trend. The distribution of average NFCI/PE ratio by banks is presented in Figure 7.

A detailed review of NFCI/PE by banks and countries reveals that UniCredit is the bank with most frequently occurring high values of this indicator (over one) within the selected countries (five out of seven banks). The next one is Raiffeisen (four out of eight banks), then Societe Generale (two out of seven banks) and finally Banca Intesa (one out of seven banks). The overview of NFCI/PE ratios by banks and countries in 2015 is presented in Figure 8.

\section{CONCLUSIONS}

The herein conducted research involves two stages. In the first stage we analyse the absolute values of three indicators: net fee and commission income compared to net interest income (NFCI/NII), impairment losses on loans compared to net interest income (ILL/NII), and net fee and commission income compared to personnel expenses (NFCI/PE) of 29 banks that are members of one of the four banking groups (Banca Intesa, UniCredit, Raiffeisen and Societe Generale) within nine Central and Eastern European (CEE) countries. In the second stage, we analyze the differences and similarities between banks based on their group and country affiliation.

The analysis of the NFCI/NII ratios of individual banks by countries and by bank groups in 2014 and 2015 reveals that in most countries all of the banks income follows similar pattern. Moreover, the ranking of banks based on the value of NFCI/NII ratio within individual countries varies from country to country. The differences are obvious within various countries. The NFCI/NII ratios of Albanian banks are the lowest, followed by Serbian banks, then by Croatian banks, Slovak banks, Czech banks, Bulgarian banks, Romanian banks, Slovenian banks, and finally by Hungarian banks,
Distribution of country average ratios "impairment losses on loans / net interest income" (IIL/NII) in 2014 and 2015 varied from country to country. Czech and Slovak banks' loan portfolios were the healthiest banks at that time. On the contrary, Hungarian and Romanian banks experienced the greatest loan losses compared to their net interest income in both years, especially in 2014. In order to avoid high variances among the banks over the period of two years, we calculated summarized ILL/NII ratio for two years by banks and by countries. The analysis of the results reveals that Raiffeisen bank in Hungary had ultimately the worst experience among all banks, followed by Banca Intesa in Romania and Banca Intesa in Hungary.

The analysis of the share of personnel expenses financed by fee and commission income (NFCI/PE ratio) shows that banks' net fee and commission income are usually not sufficient for financing personal expenses. The NFCI/PE ratio was the lowest in Albania in 2014, it had very similar values for Romanian, Slovenian, Croatian, Serbian, Czech and Slovak banks, and the highest values for Bulgarian and Hungarian banks, which are able to finance their personnel expenses fully by net fee and commission income.

Higher weights of "net fee and commission income / personnel expenses" (NFCI/PE) ratios in 2015 than in 2014, in all countries except for Romania, is the most significant characteristic of (NFCI/PE) trend.

The final objective of this paper is to examine which of two factors, the banking group's policies or the country environment, has higher impact on the above results of banks' operations. The overall results reveal that, in spite of strong group management policies, the results of individual banks from the same group vary from country to country, and that there are more similarities among banks from various groups in the same country that among the banks from the same group coming from different countries. We may conclude that the country environment has a considerably higher impact on the results of bank's operations than group management policies. 


\section{REFERENCES}

Delis, M.D. (2008). Competitive conditions in the Central and Eastern European banking systems. Online at http://mpra. ub.uni-muenchen.de/13890/. MPRA Paper No. 13890, posted 10. March 2009 05:42 UTC.

Dietsch, M., \& Lozano-Vivas, A. (2000). How the environment determines banking efficiency: A comparison between French and Spanish industries. Journal of Banking \& Finance, 24 985-1004.

Fries, S., Neven, D., \& Seabright, P. (2002). Bank performance in transition economies. Working paper No. 76, European Bank for Reconstruction and Development.

Hoffmann, P. S. (2011). Determinants of the Profitability of the US Banking Industry. International Journal of Business and Social Science, 2(22).

IIRC. (2013). The international $<$ IR $>$ framework, International Integrated Reporting Council (IIRC). Available on www. theiirc.org

Monea, M. (2011). Analysis of Incomes, Expenses and Profitability in Banks. Annals of the University of Petrosani-Economics.

Raiffeisen Bank. (2016). Raiffeisen RESEARCH, CEE Banking Sector Report. Available on http:// www.rbinternational.com/eBusiness/01_template1/829189266947841370-829189181316930732_8296

02947997338151_829603177241218127-82960317724

1218127-NA-2-EN.html.

\section{Appendix 1: List of banks}

Banca Intesa

- Banca COMERCIALA INTESA SANPAOlO ROMANiA S.A. (INTESA SANPAOLO BANK Romania), Financial statements 31 December 2015 Prepared in accordance with International Financial Reporting Standards as endorsed by the European Union.

- BANCA INTESA Beograd, Godišnji izveštaj 2015.

- BANKA KOPER (Bank of INTESA SANPAOLO GROUP), Annual Report 2015.

- CIB BANK ltd. and its subsidiaries (Bank of INTESA SANPAOLO), Consolidated Financial Statements for the year ended 31 December 2015 prepared in accordance with International Financial Reporting Standards as adopted by EU, with the report of the Independent Auditor.

- INTESA SANPAOLO BANK Albania, Annual Report 2015.

- PRIVREDNA BANKA ZAGREB, Godišnje izvješće 2015.

- VÚB BANKA (a bank of INTESA SANPAOLO), Annual Report 2015.
Reiffeisen

- Raiffeisen bank a.s. Czech, Annual Report 2015.

- Raiffeisen bank Bulgaria, Annual Report 2015.

- Raiffeisen bank Hungary, Annual Report 2015.

- Raiffeisen Bank S.A. Romania, Annual Report 2015.

- Raiffeisen Bank sh.a. Albania, Raporti i audituesit të pavarur dhe Pasqyratfinanciare individuale më dhe për vitin e mbyllur më31 dhjetor 2015.

- Raiffeisen banka a.d. Beograd, Annual Report 2015.

- Raiffeisenbank Austria d.d. Zagreb, Godišnje izvješće 2015.

- Tatra banka (Member of Faiffeisen Bank International) Slovak Republic, Annual Report 2015.

Societe Generale

- BRD - Groupe Société Générale S.A. Romania, Consolidated and separate financial statements December 31, 2015.

- Komerční banka, a.s. (member of the Societe Generale international financial group), Annual Report 2015.

- SKB Bank d.d. (Societe General Group) Nerevidirani nekonsolidirani računovodski izkazi 2015.

- SKB Slovenia, Annual Report 2015.

- SOCIETE GENERALE - SPLITSKA BANKA d.d. 2015., Godišnje izvješće.

- Societe Generale Albania, Annual Report 2015.

- Societe Generale Banka Srbija AD Beograd, Pojedinačni finansijski izveštaji i napomene uz pojedinačne finansijske izveštaje na dan 31.decembar 2015.godine.

- СОСИЕТЕ ЖЕНЕРАЛ ЕКСПРЕСБАНК, АД, ГодишњН индивидуален доклад за дейността, доклад на независимия одитор и годишен индивидуален финансовотчет кЂм 31 декембри 2015. г.

UniCredit

- UniCredit Bank Czech Republic and Slovakia, a.s., 2015 Consolidated Reports and Accounts.

- UniCredit Bank Hungary Zrt., 2015 Consolidated Reports and Accounts.

- UniCredit Bank S.A., Separate Financial Statements 31 Decembaer 2015.

- UniCredit Bank Srbija a.d. Beograd, Godišnji izveštaj 2015.

- UniCredit Banka Slovenija d.d., 2015 Letno poročilo / Annual Report.

- Zagrebačka banka d.d. (UniCredit Group), Godišnje izvješće za 2015.

- УниКредит Булбанк АД, 2015 Годишен отчет.

\section{UČINAK POLITIKA UPRAVLJANJA NA NIVOU BANKARSKE GRUPE I OKRUŽENJA ZEMLJE U KOJOJ BANKA POSLUJE NA MODEL POSLOVANJA BANKE}

\footnotetext{
Apstrakt:

Cilj ovog rada jeste da pokuša da prepozna koji od sledeća dva faktora: (1) politike upravljanja uspostavljene na nivou bankarske grupe ili (2) okruženje u zemlji u kojoj banka posluje, ima veći učinak na model poslovanja banke, mereno putem tri pokazatelja poslovanja: neto prihod od naknada prema neto prihodu od kamata, gubici po osnovu obezvređenih plasmana prema neto prihodu od kamata, i neto prihod od naknada prema troškovima zarada zaposlenih. Analiza obuhvata 29 banaka koje posluju u devet zemalja centralne i istočne Evrope u okviru četiri bankarske grupe, tokom 2014. i 2015. godine. Rezultati istraživanja pokazuju da je uticaj okruženja zemlje u kojoj banka posluje znatno veći od uticaja koji na model poslovanja banke imaju poslovne politike uspostavljene na nivou bankarske grupe.
}

\section{Ključne reči:}

poslovanje banaka na području nekoliko zemalja, efikasnost poslovanja banaka, model poslovanja banaka, banke u centralnoj i istočnoj Evropi. 